\title{
Ena/VASP-Like Protein
}

National Cancer Institute

\section{Source}

National Cancer Institute. Ena/VASP-Like Protein. NCI Thesaurus. Code C114829.

Ena/VASP-like protein $(416 \mathrm{aa}, \sim 45 \mathrm{kDa}$ ) is encoded by the human EVL gene. This protein is involved in actin binding and cytoskeletal remodeling. 